\title{
Management of mammalian target of rapamycin inhibitor-associated noninfectious pneumonitis in advanced breast cancer: A nursing perspective
}

\author{
Grace Bendinger ${ }^{* 1}$, Rabih I. Bechara ${ }^{2}$, James M. Reuben ${ }^{3}$, Ricardo H. Alvarez ${ }^{1}$ \\ ${ }^{1}$ Cancer Treatment Centers of America, Newnan, GA, United States \\ ${ }^{2}$ Georgia Regents University School of Medicine, Augusta, GA, United States \\ ${ }^{3}$ Department of Hematopathology, The University of Texas MD Anderson Cancer Center, Houston, TX, United States
}

Received: February 10, 2016

Accepted: June 13, 2016

Online Published: October 30, 2016

DOI: $10.5430 /$ jnep.v7n3p57

URL: http://dx.doi.org/10.5430/jnep.v7n3p57

\begin{abstract}
The identification of the disease progression and drug resistance pathways involved in breast cancer led to the development of mammalian target of rapamycin (mTOR) inhibitors. Since their introduction, mTOR inhibitors have improved clinical outcomes in patients with advanced breast cancer. These agents are generally well tolerated, but they have a unique adverse event (AE) profile of which clinicians and nurses should be aware. Although rare, noninfectious pneumonitis (NIP) is one such mTOR-associated $\mathrm{AE}$ that is generally mild and manageable, but it can result in severe or potentially life-threatening toxicity. Previous clinical experience with everolimus and temsirolimus in renal cell carcinoma has led to the development of guidelines for the diagnosis and management of mTOR-associated AEs, including NIP. However, specific guidelines in the advanced breast cancer setting are currently lacking. Herein we review the available literature regarding the development of mTOR-associated NIP in patients with advanced breast cancer. In addition, we have developed a set of guidelines that will provide nurses with appropriate management strategies for the treatment of mTOR inhibitor-associated NIP in patients with advanced breast cancer.
\end{abstract}

Key Words: Everolimus, Breast cancer, Pneumonitis, Adverse drug event

\section{INTRODUCTION}

After lung cancer, breast cancer is the second most common type of cancer worldwide, with an estimated 1.67 million new cases a year. ${ }^{[1]}$ In the United States, breast cancer is the most commonly diagnosed cancer in women and the second leading cause of cancer death in women after lung cancer. ${ }^{[2]}$ Although significant advances in the management of breast cancer have led to improvements in patient survival, ${ }^{[3]}$ advanced breast cancer remains challenging to treat due to acquired or inherent resistance to therapy. ${ }^{[4]}$ In particular, disease progression in patients with breast cancer with hormone receptor (HR)-positive tumors receiving endocrine therapies is common due to resistance to these agents. ${ }^{[5]}$

Dysregulation of the phosphatidylinositol 3-kinase (PI3K)/AKT/mammalian target of rapamycin (mTOR) signal transduction pathway has been implicated as a mechanism of resistance in many human cancers, including renal cell carcinoma (RCC) and breast cancer. ${ }^{[5-7]}$ Furthermore, research has demonstrated a link between the PI3K/AKT/mTOR and estrogen receptor (ER) pathways in the development of breast cancer progression and resistance to endocrine therapy. ${ }^{[8]}$ Therefore, inhibition of the PI3K/AKT/mTOR

\footnotetext{
*Correspondence: Grace Bendinger; Email: grace.bendinger@ctca-hope.com; Address: Cancer Treatment Centers of America, 600 Parkway North,
} Newnan, GA, United States. 
pathway represents a promising target for the treatment of breast cancer. ${ }^{[9,10]}$

The identification of pathways implicated in disease progression and resistance to endocrine therapies in breast cancer has resulted in the emergence of new, advanced, targeted therapeutic agents for breast cancer (e.g., mTOR inhibitors) that have improved clinical outcomes in patients with this disease. ${ }^{[11]}$ Although these targeted agents are generally well tolerated, healthcare practitioners should be aware of the unique adverse event (AE) profiles that have been observed. ${ }^{[12,13]}$ One such AE associated with mTOR-inhibitor therapy is noninfectious pneumonitis (NIP), which represents one of the most common AEs leading to treatment discontinuation. ${ }^{[14]}$ Although generally mild in severity, mTOR inhibitor-associated NIP can potentially result in severe outcomes, which emphasizes the importance of early recognition and prompt management by healthcare practitioners.

This article provides an overview of the role of mTOR inhibitors and their clinical efficacy and safety in advanced breast cancer, followed by a discussion on the recognition, diagnosis, and management of mTOR-associated NIP.

\section{BREAST CANCER EPIDEMIOLOGY}

The American Cancer Society estimated that in the United States, 231,840 new cases of breast cancer would be diagnosed in 2015 and that 40,290 women would die from the disease. ${ }^{[2]}$ At diagnosis, most patients with breast cancer have localized disease $(61 \%)$ or regional lymph node involvement $(33 \%)$, whereas $5 \%$ have metastatic disease at diagnosis. ${ }^{[3]}$ Five-year survival rates are high for patients with localized disease (99\%) or regional lymph node involvement (84\%), but they drop substantially in those with metastatic disease $(24 \%) .{ }^{[13]}$ More than $75 \%$ of patients with advanced breast cancer have HR-positive disease, ${ }^{[15,16]}$ which is often initially managed with endocrine therapy. ${ }^{[15]}$

\section{THE ROLE OF MTOR INHIBITORS}

Patients with HR-positive advanced breast cancer generally respond well to endocrine therapies, such as nonsteroidal aromatase inhibitors (e.g., anastrozole, letrozole), steroidal aromatase inhibitors (exemestane), and nonsteroidal selective ER modulators (tamoxifen). In postmenopausal women with HR-positive advanced breast cancer, first-line treatment with these endocrine therapies is recommended by treatment guidelines. ${ }^{[5]}$ However, some patients do not respond to firstline endocrine therapy (i.e., inherent resistance), or their disease eventually progresses despite an initial response to firstline treatment (i.e., acquired resistance). ${ }^{[1,17]}$ In patients with disease progression after first-line endocrine therapy, second-line options include the use of other aromatase in- hibitors and ER modulators (e.g., tamoxifen, fulvestrant). ${ }^{[5]}$ The need for additional treatment options in second- and subsequent-line settings after disease progression has led researchers to study pathways of endocrine resistance, such as the mTOR signaling pathway, in an attempt to develop new targeted agents for the treatment of advanced breast cancer. ${ }^{[18]}$

mTOR, an intracellular protein kinase, is a key component of the PI3K/AKT/mTOR signal transduction pathway, which plays a critical role in regulating cellular proliferation, survival, and differentiation. ${ }^{[6,19,20]}$ In breast cancer, this pathway is frequently mutated and hyperactive, ${ }^{[9,21,22]}$ and this contributes to the development of aggressive cancer phenotypes $^{[23]}$ and resistance to endocrine therapy. ${ }^{[8,10]}$ It has been hypothesized that the use of mTOR inhibitors may either partially restore sensitivity to endocrine therapies in patients with acquired resistance or delay the onset of resistance when used in combination with current therapies. ${ }^{[10,24,25]}$

To date, two mTOR inhibitors have been approved by the FDA for cancer treatment. Everolimus is an oral mTOR inhibitor that has been approved for use in many cancer types, including RCC, pancreatic neuroendocrine tumor, subependymal giant cell astrocytomas, and renal angiomyolipoma in tuberous sclerosis complex. ${ }^{[26]}$ Most recently, everolimus was approved for use in combination with an aromatase inhibitor (exemestane) for the treatment of postmenopausal women with advanced, HR-positive, human epidermal growth factor receptor 2 (HER2)-negative breast cancer who are resistant to endocrine therapy (e.g., letrozole, anastrozole). ${ }^{[26]}$ The second approved mTOR inhibitor, temsirolimus, is intravenously administered and approved only for use in the treatment of advanced RCC. ${ }^{\text {[27] }}$

\section{Clinical experience OF MTOR IN- HIBITORS IN ADVANCED BREAST CANCER}

Overall, a number of clinical trials have demonstrated the efficacy and safety of mTOR inhibitors in advanced breast cancer, with the bulk of the data focusing on everolimus either alone or as part of combination therapy (see Table 1). ${ }^{[11,14,28-33]}$

\subsection{Efficacy}

The overall response rates of everolimus reported in phase 1 or 2 trials ranged from $12 \%-44 \%$ (see Table 1). ${ }^{[28,29,31,32]}$ In addition, everolimus and temsirolimus were both evaluated as part of combination therapy in two international, double-blind, randomized, placebo-controlled phase 3 trials of postmenopausal patients with advanced breast cancer (i.e., the BOLERO-2 and HORIZON trials). ${ }^{[1,33]}$ 
Table 1. Summary of major clinical trials of mammalian target of rapamycin inhibitor therapy in patients with advanced breast cancer

\begin{tabular}{|c|c|c|c|}
\hline Study & Treatment & Main Efficacy Outcomes & Safety Outcomes \\
\hline $\begin{array}{l}\text { Baselga et al. }(2012) \text {; } \\
\text { Yardley et al. }(2013)^{[14]} \\
\text { (BOLERO-2) } \\
\text { Pivotal, randomized, } \\
\text { phase } 3 \text { trial }(\mathrm{N}=724)\end{array}$ & $\begin{array}{l}\text { Everolimus } 10 \mathrm{mg} / \text { day }+ \\
\text { exemestane } \\
\text { vs. } \\
\text { Placebo + exemestane }\end{array}$ & $\begin{array}{l}\text { Median PFS (18-mo follow-up) } \\
\text { Local review: } 7.8 \text { vs. } 3.2 \text { mo } \\
\text { Central review: } 11.0 \text { vs. } 4.1 \text { mo } \\
\text { ORR (18-mo follow-up) } \\
\text { Local review: } 12.6 \% \text { vs. } 1.7 \% \\
\text { Central review: } 12.6 \% \text { vs. } 2.1 \% \\
\text { CBR* (18-mo follow-up) } \\
\text { Local review: } 51.3 \% \text { vs. } 26.4 \% \\
\text { Central review: } 49.9 \% \text { vs. } 22.2 \%\end{array}$ & $\begin{array}{l}\text { Common Grade } 3 / 4 \text { AEs } \\
\text { Stomatitis, anemia, dyspnea, } \\
\text { hyperglycemia, fatigue, and } \\
\text { pneumonitis, GGT increased } \\
\text { Common AEs leading to } \\
\underline{\text { discontinuation }} \\
\text { Pneumonitis, stomatitis }\end{array}$ \\
\hline $\begin{array}{l}\text { Bachelot et al. } \\
(2012)^{[29]} \\
(\text { TAMRAD) } \\
\text { Randomized, phase } 2 \\
\text { trial }(\mathrm{N}=111)\end{array}$ & $\begin{array}{l}\text { Everolimus } 10 \mathrm{mg} / \mathrm{day}+ \\
\text { tamoxifen } \\
\text { vs. } \\
\text { Placebo + tamoxifen }\end{array}$ & $\begin{array}{l}\frac{\mathrm{CBR} *}{61 \% \text { vs. } 62 \%} \\
\frac{\text { Response rate }}{14 \% \text { vs. } 13 \%} \\
\underline{\text { Median OS }} \\
\text { Not reached vs. } 32.9 \mathrm{mo} \\
\frac{\text { Median TTP }}{8.6 \text { vs. } 4.5 \mathrm{mo}}\end{array}$ & $\begin{array}{l}\text { Common Grade } 3 / 4 \text { AEs } \\
\text { Stomatitis, fatigue, pain, } \\
\text { infection, anorexia, rash, } \\
\text { pneumonitis, nausea, vomiting }\end{array}$ \\
\hline $\begin{array}{l}\text { Ellard et al. }(2009)^{[28]} \\
\text { Randomized phase } 2 \\
\text { trial }(\mathrm{N}=49)\end{array}$ & $\begin{array}{l}\text { Everolimus } 10 \mathrm{mg} / \text { day } \\
\text { Everolimus } 70 \mathrm{mg} \text { weekly }\end{array}$ & $\frac{\text { ORR }(\mathrm{CR}+\mathrm{PR})}{\text { Overall } 12 \%}$ & $\begin{array}{l}\text { Common Grade } 3 / 4 \text { AEs } \\
\text { Fatigue, pneumonitis, } \\
\text { infection, neutropenia }\end{array}$ \\
\hline $\begin{array}{l}\text { Andre et al. }(2010)^{[31]} \\
\text { Phase } 1 \text { trial }(\mathrm{N}=33)\end{array}$ & $\begin{array}{l}\text { Everolimus } 5 \mathrm{mg} / \text { day } \\
\text { Everolimus } 10 \mathrm{mg} \text { /day } \\
\text { Everolimus } 30 \mathrm{mg} \text { weekly } \\
\text { (all in combination with } \\
\text { paclitaxel and trastuzumab) }\end{array}$ & $\begin{array}{l}\text { ORR }(\mathrm{CR}+\mathrm{PR}) \\
\text { Overall } 44 \% \\
\text { CBR }^{*} \\
\text { Overall } 74 \% \\
\text { Median PFS } \\
\text { Overall } 34 \mathrm{wk}\end{array}$ & $\begin{array}{l}\text { Common Grade } 3 / 4 \text { AEs } \\
\text { Neutropenia, lymphopenia, } \\
\text { leukopenia, stomatitis, NIP }\end{array}$ \\
\hline $\begin{array}{l}\text { Schwarzlose-Schwarck } \\
\text { et al. }(2012)^{[32]} \\
\text { Phase } 1 \text { trial }(\mathrm{N}=15)\end{array}$ & $\begin{array}{l}\text { Everolimus } 2.5,5,7.5 \text {, and } 10 \\
\text { mg/day (all with carboplatin } \\
\text { weekly) }\end{array}$ & $\begin{array}{l}\text { Overall response rate } \\
21 \% \\
\underline{\text { Median PFS }} \\
19 \mathrm{wk} \\
\underline{\text { Median OS }} \\
35.3 \mathrm{wk}\end{array}$ & $\frac{\text { Common Grade } 3 / 4 \text { AEs }}{\text { Thrombocytopenia, leukopenia }}$ \\
\hline $\begin{array}{l}\text { Wolff et al. }(2013)^{[33]} \\
\text { (HORIZON) } \\
\text { Randomized, phase } 3 \\
\text { trial }(\mathrm{N}=1,112)\end{array}$ & $\begin{array}{l}\text { Temsirolimus } 30 \mathrm{mg} / \text { day }+ \\
\text { letrozole } \\
\text { vs. } \\
\text { Placebo + letrozole }\end{array}$ & $\begin{array}{l}\text { Median PFS } \\
8.9 \text { vs. } 9.0 \text { mo } \\
\text { Median OS } \\
\text { Not reached } \\
\frac{\text { ORR }}{27 \% \text { vs. } 27 \%}\end{array}$ & $\begin{array}{l}\text { Common Grade } 3 / 4 \text { TEAEs } \\
\text { Dyspnea, hyperglycemia, } \\
\text { diarrhea, mucositis/stomatitis, } \\
\text { hyperlipidemia, asthenia }\end{array}$ \\
\hline
\end{tabular}

Note. Abbreviations: AE, adverse event; CBR, clinical benefit rate; CR, completed response; GGT, gamma-glutamyltransferase; mo, month(s); NIP, noninfectious pneumonitis; ORR, objective response rate; OS, overall survival; PFS, progression-free survival; PR, partial response; SD, stable disease; TEAE, treatment-emergent adverse event; wk, week(s). *CR + PR + (SD $\geq 24$ weeks).

The approval of everolimus for the treatment of advanced HR-positive, HER2-negative, postmenopausal breast cancer was based on findings from the pivotal BOLERO-2 trial. ${ }^{[1]}$ A total of 724 postmenopausal patients whose disease had progressed on nonsteroidal aromatase inhibitors were treated with oral everolimus $10 \mathrm{mg} /$ day or matching placebo in combination with exemestane $25 \mathrm{mg} /$ day. ${ }^{[1]}$ The combination of everolimus plus exemestane significantly prolonged median progression-free survival (PFS) versus placebo plus exemestane as assessed by local review (6.9 vs. 2.8 months; $P<$ $.001)$ and central review (10.6 vs. 4.1 months; $P<.001)$. At the final PFS analysis the benefit of everolimus plus exemestane over placebo plus exemestane for median PFS was also maintained when assessed by both local review (7.8 vs. 3.2 
months; $P<.0001)$ and central review (11.0 vs. 4.1 months; $P<.0001){ }^{[14]}$

The HORIZON trial $(\mathrm{N}=1,112)$ evaluated first-line therapy with oral temsirolimus $30 \mathrm{mg} /$ day plus letrozole $2.5 \mathrm{mg} /$ day in postmenopausal women with ER-positive and/or progesterone receptor-positive locally advanced or metastatic breast cancer with no prior exposure to aromatase inhibitors. ${ }^{[33]}$ No improvement in median PFS was seen with temsirolimus plus letrozole versus letrozole alone ( $8.9 \mathrm{vs}$. 9.0 months; $P=.50$ ).

\subsection{Safety}

Commonly reported AEs associated with mTOR inhibitor therapy include stomatitis/mucositis, NIP, infection, hyperglycemia, rash, and hyperlipidemia. ${ }^{[13,34]}$ The results of clinical trials indicated that mTOR inhibitor therapy is generally well tolerated, with low incidence rates of grade 3 or 4 AEs. ${ }^{[11,14,28-33]}$ In clinical trials of everolimus and temsirolimus in advanced breast cancer, the most common grade 3 or 4 treatment-associated AEs included stomatitis, fatigue, infection, dyspnea, hyperglycemia, anemia, NIP, diarrhea, hyperlipidemia, asthenia, and elevated gammaglutamyltransferase (see Table 1). ${ }^{[11,14,28,29,31-33]}$

The close monitoring and early recognition of mTOR inhibitor-associated AEs by healthcare practitioners (e.g., oncology nurses) and the subsequent prompt intervention in patient care can reduce the severity of these AEs, enhance treatment tolerability, improve quality of life, and potentially lead to improvements in patient outcomes. ${ }^{[34-36]}$ In addition to the early recognition of AEs, it is important that healthcare practitioners assess their initial severity so that appropriate management strategies can be implemented. AE severity can be descriptively assessed via the National Cancer Institute's Common Terminology Criteria for Adverse Events (CTCAE), version 4.03, which uses a grading scale to determine the severity of specific AEs, including NIP (see Table 2).

Table 2. Summary of the grading system for adverse event and noninfectious pneumonitis severity according to the National Institutes of Health and National Cancer Institute Common Terminology Criteria for Adverse Events, version 4.03 ${ }^{[45]}$

\begin{tabular}{|c|c|c|}
\hline \multicolumn{2}{|c|}{ Clinical Description for AE Severity } & \multirow{2}{*}{$\begin{array}{l}\text { Clinical Description for NIP Severity } \\
\text { Asymptomatic; clinical or diagnostic observations only; } \\
\text { intervention not indicated }\end{array}$} \\
\hline Grade 1 & $\begin{array}{l}\text { Mild; asymptomatic or mild symptoms; clinical or diagnostic } \\
\text { observations only; intervention not indicated }\end{array}$ & \\
\hline Grade 2 & $\begin{array}{l}\text { Moderate; minimal, local or noninvasive intervention indicated; } \\
\text { limiting age-appropriate instrumental ADL* }\end{array}$ & $\begin{array}{l}\text { Symptomatic; medical intervention indicated; limiting } \\
\text { instrumental ADL* }\end{array}$ \\
\hline Grade 3 & $\begin{array}{l}\text { Severe or medically significant but not immediately } \\
\text { life-threatening; hospitalization or prolongation of } \\
\text { hospitalization indicated; disabling; limiting self-care ADL† }\end{array}$ & $\begin{array}{l}\text { Severe symptoms; limiting self-care ADL†; oxygen } \\
\text { indicated }\end{array}$ \\
\hline Grade 4 & Life-threatening consequences; urgent intervention indicated & $\begin{array}{l}\text { Life-threatening respiratory compromise; urgent } \\
\text { intervention indicated (e.g., tracheotomy or intubation) }\end{array}$ \\
\hline Grade 5 & Death related to $\mathrm{AE}$ & Death \\
\hline
\end{tabular}

\section{NONINFECTIOUS PNEUMONITIS}

\subsection{Overview}

NIP is a drug class effect of mTOR inhibitor therapy that is characterized by a nonmalignant infiltration of the lungs. ${ }^{[4,34-36]}$ There is evidence to suggest that the occurrence of this mTOR-associated toxicity may be schedule dependent, with higher incidence rates reported during daily versus weekly treatment with everolimus (49\% vs. $19 \%)$. ${ }^{[28]}$ Although this pulmonary toxicity can be potentially serious if left untreated, NIP is usually manageable and reversible upon drug discontinuation. ${ }^{[4]}$

\subsection{Clinical presentation}

NIP can be difficult to diagnose or misdiagnosed because patients may be asymptomatic or present with mild, nonspecific respiratory symptoms, including cough, dyspnea, hypoxia, and pleural effusion on rare occasions. ${ }^{[4,36]}$ Fever may also be present, making it difficult to distinguish NIP from infectious causes. ${ }^{[4]}$ Hemoptysis has also been observed, and deaths, although rare, have been reported. ${ }^{[4]}$

\subsection{Diagnosis}

To facilitate the accurate diagnosis of NIP, a computed tomography (CT) scan and lung function tests, including single breath transfer factor for carbon monoxide (TLCO) and arterial oxygen saturation, should be performed in patients with baseline respiratory symptoms or documented pulmonary metastases prior to initiation of mTOR inhibitors (e.g., everolimus). ${ }^{[37]}$ NIP should be suspected in patients who present with cough or dyspnea with or without hy- 
poxia and/or pleural effusion during mTOR inhibitor therapy. ${ }^{[38]}$ Chest radiographic imaging should be performed in patients with suspected NIP, but findings may be subtle and diagnosis usually requires $\mathrm{CT}$ chest scans, which provide greater sensitivity and specificity. ${ }^{[4]}$ Radiographic findings consistent with NIP include ground glass opacities, diffuse patchy airspace disease, and focal consolidation (see Figure 1). ${ }^{[7,36,37,39]}$ Finally, bronchoscopy with bronchoalveolar lavage (BAL) with or without biopsy may also be required to exclude infectious or malignant causes. ${ }^{[4]}$

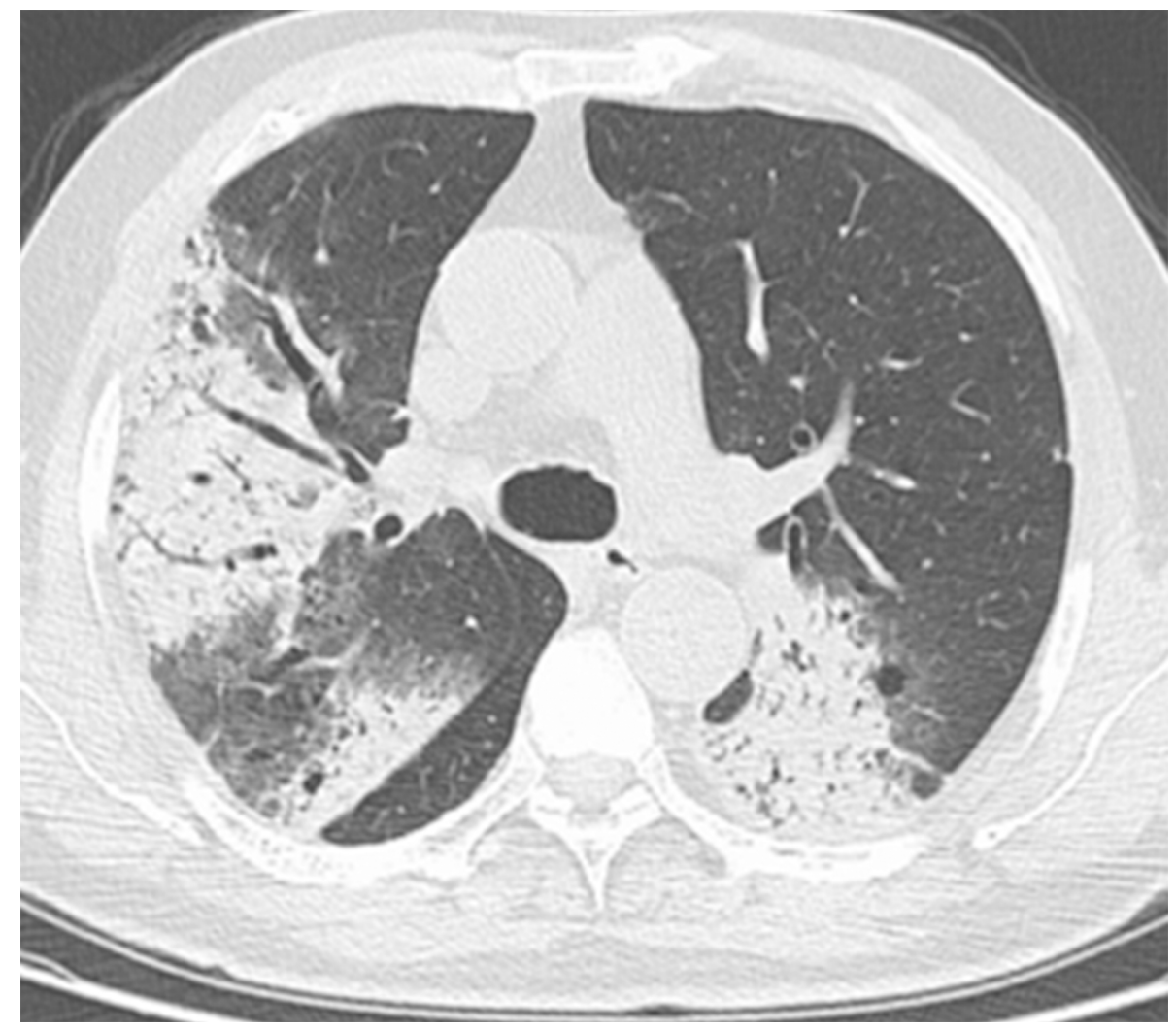

Figure 1. Computed tomography chest scan images of a 59-year-old female patient with radiological signs of noninfectious pneumonitis following treatment with everolimus $10 \mathrm{mg}$ and exemestane $25 \mathrm{mg}$ for 1 year.

\subsection{Data from clinical trials}

mTOR inhibitors were first approved for the treatment of advanced RCC; therefore, the initial mTOR inhibitor-associated NIP data were obtained from this patient population. ${ }^{[26,27]}$ A retrospective review of clinical data and CT chest scans from temsirolimus- or everolimus-treated patients showed that $30 \%$ of patients had CT evidence of NIP. ${ }^{[40]}$ In the pivotal RECORD-1 trial, all-grade everolimusassociated NIP was reported in $13.5 \%$ of patients, with a median time to onset of pneumonitis of 108 days; $;{ }^{[41]}$ however, a radiographic review indicated that $39 \%$ of patients without a diagnosis of pneumonitis had radiologic evidence of pneumonitis. ${ }^{[39]}$

Clinical trial data for mTOR inhibitor-treated patients with advanced breast cancer and NIP are summarized in Table 3. ${ }^{[11,14,28-33,42]}$ These trials showed that all-grade everolimus-associated NIP incidence rates varied, ranging from $0 \%-42 \%$ of patients; the incidence of grade 3 or 4

Published by Sciedu Press
NIP was low (0\%-9\%) across these studies, and the incidence of NIP leading to treatment discontinuation ranged from $0 \%-12 \% .{ }^{[11,14,28-32,42]}$ It should be noted, however, that mTOR inhibitor-associated NIP may be underreported in these studies because some patients may have been asymptomatic and others may have presented with nonspecific respiratory symptoms that were attributed to another cause. ${ }^{[13]}$ A more in-depth analysis of everolimus-associated AEs in the BOLERO-2 trial revealed that approximately $25 \%$ of all-grade $\geq 2$ NIP events occurred within the first 12 weeks of therapy, with cumulative event risk increasing with prolonged exposure $(5 \%, 10 \%$, and $16 \%$ at 12,24 , and 48 weeks, respectively). ${ }^{[42]}$ Resolution to grade $\leq 1$ NIP was achieved by $80 \%$ of patients with grade 3 NIP following dose interruption or reduction after a median of 3.8 weeks. ${ }^{[42]}$ In addition, complete resolution of NIP was achieved by the majority of patients $(75 \%)$ after a median of 5.4 weeks. ${ }^{[42]} \mathrm{A}$ total of $5.6 \%$ of patients required treatment discontinuation due to $\mathrm{NIP}^{[42]}$ 
Table 3. Summary of noninfectious pneumonitis clinical data in clinical trials of mammalian target of rapamycin inhibitor therapy in advanced breast cancer

\begin{tabular}{|c|c|c|c|c|c|}
\hline \multirow{3}{*}{ Study } & \multirow{3}{*}{ Treatment } & \multicolumn{4}{|l|}{ \% Patients } \\
\hline & & \multicolumn{2}{|c|}{ NIP incidence } & \multirow{2}{*}{$\begin{array}{l}\text { Dose } \\
\text { Interruptions } \\
\text { or Reductions }\end{array}$} & \multirow{2}{*}{$\begin{array}{l}\text { NIP Leading to } \\
\text { Treatment } \\
\text { Discontinuation }\end{array}$} \\
\hline & & Any Grade & Grade 3 or 4 & & \\
\hline \multirow{4}{*}{$\begin{array}{l}\text { Baselga et al. } \\
\text { (2012); }{ }^{[11]} \text { Yardley et } \\
\text { al. (2013); }{ }^{[14]} \text { Rugo et } \\
\text { al. (2014) })^{[42]} \\
\text { (BOLERO-2) }\end{array}$} & $\begin{array}{l}\text { Everolimus + exemestane (median } \\
\text { exposure } 14.6 \mathrm{wk})^{[11]}\end{array}$ & 12 & $3 *$ & NR & NR \\
\hline & $\begin{array}{l}\text { Placebo + exemestane (median } \\
\text { exposure } 12 \mathrm{wk})^{[11]}\end{array}$ & 0 & 0 & NR & NR \\
\hline & $\begin{array}{l}\text { Everolimus + exemestane (18-mo } \\
\text { follow-up) }^{[14,42]}\end{array}$ & 16 & 3 & 7.5 & 5.6 \\
\hline & $\begin{array}{l}\text { Placebo + exemestane (18-mo } \\
\text { follow-up) }\end{array}$ & 0 & 0 & 0 & 0 \\
\hline \multirow{2}{*}{$\begin{array}{l}\text { Bachelot et al. } \\
(2012)^{[29]} \\
\text { (TAMRAD) }\end{array}$} & $\begin{array}{l}\text { Everolimus + tamoxifen (median } \\
\text { treatment duration } 6.2 \mathrm{mo} \text { ) }\end{array}$ & 17 & 2 & 2 & 4 \\
\hline & $\begin{array}{l}\text { Tamoxifen alone (median } \\
\text { treatment duration } 4.8 \mathrm{mo} \text { ) }\end{array}$ & 4 & 4 & NR & 0 \\
\hline \multirow{2}{*}{ Ellard et al. (2009) ${ }^{[28]}$} & $\begin{array}{l}\text { Everolimus } 10 \mathrm{mg} / \text { day (treatment } \\
\text { duration } 18 \mathrm{mo} \text { ) }\end{array}$ & 42 & 9 & NR & 12 \\
\hline & $\begin{array}{l}\text { Everolimus } 70 \text { mg weekly } \\
\text { (treatment duration } 18 \mathrm{mo} \text { ) }\end{array}$ & 19 & 0 & NR & 6 \\
\hline \multirow{3}{*}{ Andre et al. (2010) ${ }^{[31]}$} & $\begin{array}{l}\text { Everolimus } 5 \mathrm{mg} / \text { day (median } \\
\text { treatment duration } 28 \mathrm{wk} \text { ) }\end{array}$ & 0 & 0 & 0 & 0 \\
\hline & $\begin{array}{l}\text { Everolimus } 10 \mathrm{mg} / \text { day (median } \\
\text { treatment duration } 28 \mathrm{wk} \text { ) }\end{array}$ & 6 & 6 & 0 & 6 \\
\hline & $\begin{array}{l}\text { Everolimus } 30 \text { mg weekly } \\
\text { (median treatment duration } 33 \text { wk) }\end{array}$ & 0 & 0 & 0 & 0 \\
\hline $\begin{array}{l}\text { Schwarzlose-Schwarck } \\
\text { et al. }(2012)^{[32]}\end{array}$ & $\begin{array}{l}\text { Everolimus 2.5, 5, 7.5, and } \\
10 \mathrm{mg} / \text { day (median treatment } \\
\text { duration } 26,6,22 \text {, and } 11 \mathrm{wk} \text {, } \\
\text { respectively) }\end{array}$ & 0 & 0 & 0 & 0 \\
\hline \multirow{2}{*}{$\begin{array}{l}\text { Wolff et al. (2013) } \\
\text { (HORIZON) }\end{array}$} & $\begin{array}{l}\text { Temsirolimus + letrozole (median } \\
\text { follow-up } 9.5 \mathrm{mo} \text { ) }\end{array}$ & NR & NR & NR & $<1$ \\
\hline & $\begin{array}{l}\text { Placebo + letrozole (median } \\
\text { follow-up } 9.5 \mathrm{mo} \text { ) }\end{array}$ & NR & NR & NR & NR \\
\hline
\end{tabular}

Note. Abbreviations: mo, month(s); NIP, noninfectious pneumonitis; NR, not reported; wk, week(s). *Paper reported that "all three patient cases of pneumonitis resolved within 15 days of everolimus discontinuation.”

\section{MANAgEMENT OF NONINFECTIOUS PNEU- 6.1 Patient counseling and education MONITIS IN BREAST CANCER}

Currently, no specific clinical guidelines have been published to guide the care of patients with advanced breast cancer who develop mTOR inhibitor-related NIP. However, earlier clinical experience with everolimus in the advanced RCC setting resulted in the establishment of guidelines in 2009 for the management of everolimus-associated AEs. ${ }^{[37]}$ The following recommendations for patients with breast cancer are based on published guidelines for the RCC population and on data from previously published clinical trials in patients with advanced breast cancer.

Patient counseling and education are both important components of care for patients with advanced breast cancer receiving mTOR inhibitor therapy. ${ }^{[4,37]}$ Prior to beginning treatment with an mTOR inhibitor, such as everolimus or temsirolimus, patients should receive adequate counseling and education to increase their awareness regarding the possible development of NIP; be routinely questioned after starting treatment about new or changing respiratory symptoms; and be advised on when to inform their healthcare provider of new or worsening respiratory symptoms. It is important that patients are informed that cough and dyspnea may be the 
first signs of NIP and that NIP can occur at any time dur- lized via the cytochrome P450 pathway and thus may have ing treatment; however, it should be emphasized that NIP symptoms are most commonly observed at the beginning of treatment. ${ }^{[43]}$ Finally, patients should also know how the mTOR inhibitors everolimus and temsirolimus are metabonumerous food-drug and drug-drug interactions that can potentially interfere with their metabolism; this can lead to greater drug toxicity or decreased drug efficacy (see Table 4). ${ }^{[26,27]}$

Table 4. Summary of CYP3A4 inducers/inhibitors and management recommendations if concomitant use with a mammalian target of rapamycin inhibitor is required ${ }^{[26,27]}$

\begin{tabular}{|c|c|c|}
\hline \multicolumn{2}{|c|}{ Agents Inducing or Inhibiting CYP3A4 Metabolism } & Management Recommendations if Concomitant Use Required \\
\hline \multicolumn{3}{|l|}{ CYP3A4 inducers } \\
\hline Strong inducers & $\begin{array}{l}\text { Rifampin, phenytoin, } \\
\text { carbamazepine, rifabutin, rifampicin, } \\
\text { rifapentine, phenobarbital, } \\
\text { dexamethasone, St. John’s wort }\end{array}$ & $\begin{array}{l}\text { Everolimus } \\
\text { - Concomitant use should be avoided. } \\
\text { - If patients require a strong CYP3A4 inducer, double the dose of everolimus and } \\
\text { assess tolerability; assess the everolimus trough concentration } 2 \text { wk after doubling } \\
\text { the dose and adjust the dose if necessary to maintain a trough concentration of } \\
5-15 \mathrm{ng} / \mathrm{mL} \text {. } \\
\text { - Return the everolimus dose to that used prior to initiating the strong CYP3A4 } \\
\text { inducer if the strong inducer is discontinued; assess everolimus trough } \\
\text { concentrations approximately } 2 \text { wk later. }\end{array}$ \\
\hline \multicolumn{3}{|l|}{ CYP3A4 inhibitors } \\
\hline Strong inhibitors & $\begin{array}{l}\text { Ketoconazole, itraconazole, } \\
\text { clarithromycin, atazanavir, } \\
\text { nefazodone, saquinavir, } \\
\text { telithromycin, ritonavir, indinavir, } \\
\text { nelfinavir, voriconazole, grapefruit } \\
\text { or grapefruit juice }\end{array}$ & $\begin{array}{l}\text { Everolimus } \\
\text { - Avoid concomitant use }\end{array}$ \\
\hline Moderate inhibitors & $\begin{array}{l}\text { Amprenavir, fosamprenavir, } \\
\text { aprepitant, erythromycin, } \\
\text { fluconazole, verapamil, diltiazem }\end{array}$ & $\begin{array}{l}\text { Everolimus } \\
\text { - Reduce everolimus dose by approximately } 50 \% \text { and administer every other day if } \\
\text { dose reduction required for patients receiving the lowest available strength and } \\
\text { maintain trough levels of } 5-15 \mathrm{ng} / \mathrm{mL} \text {. } \\
\text { - Assess everolimus trough concentrations approximately } 2 \mathrm{wk} \text { after dose reduction } \\
\text { - Resume the dose that was used prior to initiating the CYP3A4 inhibitor } 2 \text { to } 3 \\
\text { days after discontinuation of a moderate inhibitor; assess the everolimus trough } \\
\text { concentration approximately } 2 \text { wk later. }\end{array}$ \\
\hline
\end{tabular}

Note. Abbreviations: mTOR, mammalian target of rapamycin; wk, week(s).

\subsection{Management strategies}

Prior to treatment with mTOR inhibitors, such as everolimus, patients with a TLCO value of less than $40 \%$ of the predicted value and baseline respiratory symptoms or documented pulmonary metastases should not start mTOR inhibitor therapy until lung function testing has normalized. ${ }^{[37]}$ Given the potential clinical benefits of mTOR inhibitor therapy with regard to tumor response and PFS, all efforts should be made to continue treatment, to the extent possible, in order to maximize treatment outcomes. ${ }^{[4]}$ Management strategies for mTOR inhibitor-associated NIP generally comprise mTOR inhibitor dose reduction, dose interruption or discontinuation, and the use of corticosteroids; these strategies depend on the severity of symptoms and radiographic findings. It is important to note that the immunosuppressive properties of mTOR inhibitors may predispose patients to increased risk of infection or reactivation of previous infections. ${ }^{[13,37]}$

Published by Sciedu Press
Therefore, an infectious cause of pneumonitis must be ruled out, possibly by CT chest scans and BAL with or without biopsy. ${ }^{[37]}$

Once an infectious cause has been ruled out, the dose adjustment and management recommendations for AEs in the everolimus package insert may be used as a basic guide to manage mTOR inhibitor-associated NIP (see Table 5). ${ }^{[26]}$ In general, dose adjustment and AE management depend on symptom severity according to CTCAE, version 4.03. In patients with grade 1 NIP, no everolimus dose adjustment is required, but appropriate monitoring should be initiated and continued until resolution of NIP is confirmed. For the management of grade 2 NIP, everolimus dose interruption may be considered until symptoms improve to grade $\leq 1$; everolimus may be reinitiated at a lower dose (the suggested dose reduction is approximately $50 \%$ lower than the daily dose previously administered), but treatment should be discontinued 
if patients do not recover within 4 weeks. Everolimus dose interruption is recommended for grade 3 NIP until symptoms resolve to grade $\leq 1$; reinitiating everolimus at a lower dose may be considered, but treatment discontinuation should be considered if NIP recurs at grade 3. Finally, everolimus should be permanently discontinued in patients with grade 4 NIP. For grade 2-4 NIP, corticosteroid therapy may also be considered if infection is ruled out.

Table 5. Everolimus dose adjustment and management recommendations in patients with noninfectious pneumonitis ${ }^{[26]}$

\begin{tabular}{|c|c|c|}
\hline \multicolumn{3}{|c|}{ Everolimus-Associated Noninfectious Pneumonitis } \\
\hline Severity & & Everolimus Dose Adjustment and Management Recommendations \\
\hline Grade 1 & $\begin{array}{l}\text { Asymptomatic, } \\
\text { radiographic findings only }\end{array}$ & $\begin{array}{l}\text { No dose adjustment required } \\
\text { Initiate appropriate monitoring }\end{array}$ \\
\hline Grade 2 & $\begin{array}{l}\text { Symptomatic, not } \\
\text { interfering with ADL }\end{array}$ & $\begin{array}{l}\text { Consider dose interruption } \\
\text { If infection ruled out, consider corticosteroid therapy until symptoms improve to grade } \leq 1 \\
\text { Re-initiate everolimus at a lower dose* } \\
\text { Discontinue if failure to recover within } 4 \mathrm{wk}\end{array}$ \\
\hline Grade 3 & $\begin{array}{l}\text { Symptomatic, interfering } \\
\text { with ADL; oxygen } \\
\text { indicated }\end{array}$ & $\begin{array}{l}\text { Dose interruption until symptoms resolve to grade } \leq 1 \\
\text { If infection ruled out, consider corticosteroid therapy } \\
\text { Consider re-initiating everolimus at a lower dose* } \\
\text { If toxicity recurs at grade } 3 \text {, consider discontinuation }\end{array}$ \\
\hline Grade 4 & $\begin{array}{l}\text { Life-threatening, ventilator } \\
\text { support indicated }\end{array}$ & $\begin{array}{l}\text { Discontinue everolimus } \\
\text { If infection ruled out, consider corticosteroid therapy }\end{array}$ \\
\hline
\end{tabular}

Note. Abbreviations: ADL, activities of daily living; ${ }^{*}$ If a dose reduction is required, the suggested dose is approximately $50 \%$ lower than the daily dose previously administered.

Peddi and colleagues published a modified algorithm for the management of mTOR inhibitor-associated NIP in breast cancer (see Table 6). ${ }^{[4]}$ Close clinical monitoring of patients with suspected NIP is recommended, with strong consideration of pulmonary function testing and/or repeat CT chest scans to document resolution and/or improvement. The modified algorithm also graded NIP severity according to the CTCAE, version 4.03 , but divided grade 2 events into those with mild to moderate or severe/significant symptoms (i.e., cough or dyspnea). mTOR inhibitor doses should be interrupted or reduced for moderate to severe grade 2 NIP and interrupted for grade 3 events; permanent discontinuation is recommended for grade 4 NIP. Reinitiating mTOR inhibitor therapy at a reduced dose should also be considered in patients with grade 2 or 3 NIP who have recovered to grade $\leq 1$. With regard to everolimus, the recommended dose reductions are $5 \mathrm{mg}$ daily, followed by $5 \mathrm{mg}$ every other day. Given that grade 4 NIP appears to be rare (i.e., there are no reported cases in phase 3 data of patients with breast cancer), this algorithm will allow the majority of patients with advanced breast cancer who develop mTOR inhibitor-associated NIP to continue their treatment with mTOR inhibitors, although the risk of recurrent NIP is currently unknown.

Peddi and colleagues also recommended that patients consult with a pulmonary specialist to perform bronchoscopy and/or pulmonary function testing in patients with grade 3 or 4 NIP ${ }^{[4]}$ Consultation with a pulmonary specialist may also be considered for patients with grade 2 NIP and signifi- cant symptoms. With regard to corticosteroid therapy, oral prednisone or intravenous methylprednisolone (for severe cases) may be indicated once infection has been ruled out, continued until symptoms have resolved, and followed by a dose tapering. ${ }^{[4]}$ This recommendation was based on findings published in a review article by Albiges and colleagues that discussed the use of corticosteroids to treat mTOR inhibitor-associated NIP in patients with RCC ${ }^{[44]}$ Albiges and colleagues indicated that corticosteroids should be considered for grade 2 NIP and prescribed for grade 3 and 4 NIP in the form of daily oral prednisolone 0.75 to $1 \mathrm{mg} / \mathrm{kg}$ once infection has been ruled out. ${ }^{[44]}$ Intravenous methylprednisolone (2-5 mg/kg/day in two divided doses) may also be required during the first few days in patients with severe cases of NIP (grade $\geq 3$ ). ${ }^{[44]}$ Albiges and colleagues recommended that corticosteroid therapy should be continued until a response is achieved and then tapered according to symptom resolution to grades 1 or $2 \cdot{ }^{[44]}$ Furthermore, temporary concomitant corticosteroid therapy $(\leq 0.5 \mathrm{mg} / \mathrm{kg})$ may be considered upon reinitiation of mTOR inhibitor therapy in patients with grade 2 or grade 3 NIP. These recommendations also appear to be suitable for implementation in the management of mTOR inhibitor-associated NIP in the advanced breast cancer setting.

In a review article, Jerusalem and colleagues recommended the use of high-dose corticosteroid therapy ( $\geq 1 \mathrm{mg} / \mathrm{kg} / \mathrm{day}$ methylprednisolone) in symptomatic patients to achieve rapid symptomatic improvement, and indicated that high- 
dose corticosteroid therapy should be continued for $\geq 4$ uation of corticosteroids. ${ }^{[43]}$

weeks to prevent the rapid recurrence of NIP upon discontin-

Table 6. Proposed clinical algorithm for the management of mammalian target of rapamycin-associated noninfectious pneumonitis $^{[4]}$

\begin{tabular}{|c|c|c|c|c|c|}
\hline \multicolumn{6}{|c|}{ Proposed Steps Involved in the Management of mTOR-Associated NIP } \\
\hline & \multicolumn{5}{|c|}{ Grading of Symptom Severity } \\
\hline & Grade 1 & Grade 2 & & Grade 3 & Grade 4 \\
\hline & $\begin{array}{l}\text { Asymptomatic or } \\
\text { incidental identifi- } \\
\text { cation on imaging }\end{array}$ & $\begin{array}{l}\text { Mild to moderate } \\
\text { symptoms (slight } \\
\text { cough or dyspnea) }\end{array}$ & $\begin{array}{l}\text { Severe symptoms } \\
\text { (severe cough or } \\
\text { significant dyspnea) }\end{array}$ & $\begin{array}{l}\text { Symptoms interfering } \\
\text { with patient ADL }\end{array}$ & $\begin{array}{l}\text { Life-threatening } \\
\text { symptoms }\end{array}$ \\
\hline Step 1 & $\begin{array}{l}\text { - Clinical monitoring } \\
\text { - Continue full } \\
\text { mTOR inhibitor } \\
\text { dose with no dose } \\
\text { adjustment }\end{array}$ & $\begin{array}{l}\text { - Chest CT } \\
\text { - Consider mTOR } \\
\text { inhibitor dose } \\
\text { reduction if } \\
\text { symptoms } \\
\text { worsening }\end{array}$ & $\begin{array}{l}\text { - } \text { Chest CT } \\
\text { - mTOR inhibitor dose } \\
\text { reduction by } 1 \text { level or } \\
\text { interruption of } \\
\text { therapy if clinically } \\
\text { significant }\end{array}$ & $\begin{array}{l}\text { - Chest CT } \\
\text { - Consider hospitali- } \\
\text { - zation, PFT, bron- } \\
\text { - choscopy with BAL, } \\
\text { and/or biopsy } \\
\text { - Interruption of mTOR } \\
\text { inhibitor therapy }\end{array}$ & $\begin{array}{l}\text { - Hospitalization } \\
\text { - Bronchoscopy with } \\
\text { BAL and/or biopsy, } \\
\text { PFT, chest CT } \\
\text { - Discontinue mTOR } \\
\text { inhibitor therapy }\end{array}$ \\
\hline Step 2 & N/A & $\begin{array}{l}\text { - Clinical monitoring } \\
\text { - Repeat chest CT in } \\
\text { 4-8 wk }\end{array}$ & $\begin{array}{l}\text { - Consider } \\
\text { corticosteroid therapy } \\
\text { if not improving }\end{array}$ & $\begin{array}{l}\text { - Corticosteroid therapy if } \\
\text { infection ruled out }\end{array}$ & $\begin{array}{l}\text { - Corticosteroid } \\
\text { therapy if infection } \\
\text { ruled out }\end{array}$ \\
\hline Step 3 & N/A & $\mathrm{N} / \mathrm{A}$ & $\begin{array}{l}\text { - Repeat imaging in } \\
\text { 2-4 wk } \\
\text { - Consider BAL, PFT }\end{array}$ & $\begin{array}{l}\text { - Restart mTOR inhibitor } \\
\text { at a lower dose if } \\
\text { resolves to grade } \leq 1 \\
\text { - Consider repeat imaging } \\
\text { before restarting therapy }\end{array}$ & $\begin{array}{l}\text { - Permanent mTOR } \\
\text { inhibitor treatment } \\
\text { discontinuation }\end{array}$ \\
\hline Step 4 & N/A & N/A & $\begin{array}{l}\text { Consider mTOR } \\
\text { inhibitor dose } \\
\text { re-escalation if resolves } \\
\text { to grade } \leq 1\end{array}$ & $\mathrm{~N} / \mathrm{A}$ & $\mathrm{N} / \mathrm{A}$ \\
\hline
\end{tabular}

Note. Abbreviations: ADL, activities of daily living; BAL, bronchoalveolar lavage; CT, computed tomography; mTOR, mammalian target of rapamycin; N/A, not applicable; NIP, noninfectious pneumonitis; PFT, pulmonary function testing; wk, week(s).

\section{IMPLICATIONS FOR PRACTICE}

The appropriate management of mTOR-associated AEs is a crucial aspect of care for patients with breast cancer that can help to maintain the efficacy of mTOR inhibitor therapy, prevent a decreased patient quality of life, ensure adherence to therapy, and control costs associated with these issues. ${ }^{[13]}$ Therefore, the early recognition and prompt management of AEs associated with mTOR inhibitor therapy has the potential to improve overall patient outcomes. ${ }^{[13]}$ To date, everolimus is the only mTOR inhibitor approved for the treatment of patients with nonsteroidal aromatase inhibitor-resistant, HR-positive, advanced breast cancer. Oncologists and nurses involved in the care of patients with advanced breast cancer receiving everolimus must be aware of the unique $\mathrm{AE}$ profile of everolimus and work together to ensure that clinically relevant AEs are identified early and appropriate management strategies are implemented to limit the severity of toxicities, such as everolimus-associated NIP. Oncology nurses can provide patients with breast cancer with Published by Sciedu Press individualized support during their anticancer therapy, particularly with regard to the identification and management of treatment-related AEs. To optimize treatment adherence and patient outcomes, oncology nurses must also ensure that patients are educated on the recognition of symptoms associated with NIP and encouraged to promptly report these symptoms. ${ }^{[38]}$ A complete and thorough patient history should be taken, and AEs that have been observed with the use of any prior anticancer therapies and a history of any pulmonary conditions should be recorded. Given the potential for drug-drug interactions, a thorough review of concomitant medications should also be performed.

Because everolimus is an orally administered medication, patient management differs from that required with intravenously administered anticancer treatments. Healthcare providers place more emphasis on education to increase patient awareness of potential everolimus-associated AEs, such as NIP, in order to facilitate early recognition and prompt reporting of the AE. Patients should also be educated on the 
importance of attending all follow-up visits, and nurses can supply the patient with a calendar that lists follow-up visits to help patients stay on track with their treatment. ${ }^{[38]}$ Finally, oncology nurses can maintain open communication with patients receiving everolimus by performing follow-up phone calls, particularly during the first months of treatment. During these calls, nurses can help to distinguish symptoms that can be self-managed from those that may require medical at tention, and can advise patients and families accordingly. ${ }^{[38]}$

\section{Conclusion}

Generally, patients tolerate mTOR inhibitors better than traditional chemotherapy, but these targeted therapies are associated with a unique AE profile of which clinicians and nurses must be aware. Although rare, pulmonary toxicity has been documented with targeted cancer therapies, and NIP is considered to be a class effect of mTOR inhibitors. To date, there is a lack of published clinical guidelines for the management of mTOR inhibitor-associated NIP in advanced breast cancer. Clinical trial algorithms, published clinical data, and recommendations on MTOR inhibitor-associated NIP in the RCC setting may serve as guidance for the management of mTOR inhibitor-associated NIP in advanced breast cancer. However, specific guidelines must be established in this clinical setting. These guidelines will provide nurses with a solid foundation of knowledge on appropriate management strategies for mTOR inhibitor-associated NIP in patients with advanced breast cancer, thus ensuring that therapeutic goals are achieved.

\section{CONFLicts OF InTEREST Disclosure}

The authors have no conflicts of interest to declare.

\section{REFERENCES}

[1] Ferlay J, Soerjomataram I, Dikshit R, et al. Cancer incidence and mortality worldwide: sources, methods and major patterns in GLOBOCAN 2012. Int J Cancer. 2015; 136(5): E359-E386. PMid:25220842 http://dx.doi.org/10.1002/ijc. 29210

[2] American Cancer Society. Cancer Facts \& Figures. 2015. Available from: http://www.cancer.org/acs/groups/content/ Qeditorial/documents/document/acspc-044552.pdf

[3] American Cancer Society. Cancer Treatment \& Survivorship Facts \& Figures 2014-2015. Available from: http://www.cancer.org/acs/groups/content/Oresea $\mathrm{rch} /$ documents/document/acspc-042801.pdf

[4] Peddi PF, Shatsky RA, Hurvitz SA. Noninfectious pneumonitis with the use of mTOR inhibitors in breast cancer. Cancer Treat Rev. 2013; 40(2): 320-326. PMid:24011786 http://dx.doi.org/10.1016 /j.ctrv.2013.08.004

[5] National Comprehensive Cancer Network, Inc. NCCN Clinical Practice Guidelines in Oncology. Breast Cancer. 2015. Version 2.2015.

[6] Liu P, Cheng H, Roberts TM, et al. Targeting the phosphoinositide 3 kinase pathway in cancer. Nat Rev Drug Discov. 2009; 8(8): 627-644. PMid:19644473 http://dx.doi.org/10.1038/nrd2926

[7] Barber NA, Ganti AK. Pulmonary toxicities from targeted therapies: a review. Target Oncol. 2011; 6(4): 235-243. PMid:22076388 http://dx.doi.org/10.1007/s11523-011-0199-0

[8] Miller TW, Hennessy BT, Gonzalez-Angulo AM, et al. Hyperactivation of phosphatidylinositol-3 kinase promotes escape from hormone dependence in estrogen receptor-positive human breast cancer. J Clin Invest. 2010; 120(7): 2406-2413. PMid:20530877 http://dx.doi.org/10.1172/JCI41680

[9] Miller TW, Rexer BN, Garrett JT, et al. Mutations in the phosphatidylinositol 3-kinase pathway: role in tumor progression and therapeutic implications in breast cancer. Breast Cancer Res. 2011; 1(6)3: 224

[10] Rugo HS, Keck S. Reversing hormone resistance: have we found the golden key? J Clin Oncol. 2012; 30(22): 2707-2709. PMid:22753913 http://dx.doi.org/10.1200/JC0.2012.42.1271
[11] Baselga J, Campone M, Piccart M, et al. Everolimus in postmenopausal hormone receptor-positive advanced breast cancer. $\mathrm{N}$ Engl J Med. 2012; 366(6): 520-529. PMid:22149876 http://dx.d oi.org/10.1056/NEJMoa1109653

[12] Sankhala K, Mita A, Kelly K, et al. The emerging safety profile of mTOR inhibitors, a novel class of anticancer agents. Target Oncol. 2009; 4(2): 135-142. PMid:19381454 http://dx.doi.org/10. 1007/s11523-009-0107-z

[13] Yardley DA. Adverse event management of mTOR inhibitors during treatment of hormone receptor-positive advanced breast cancer: considerations for oncologists. Clin Breast Cancer. 2014; 14(5): $297-$ 308. PMid:25065566 http: //dx.doi.org/10.1016/j.clbc. 20 14.03 .002

[14] Yardley DA, Noguchi S, Pritchard KI, et al. Everolimus plus exemestane in postmenopausal patients with HR breast cancer: BOLERO-2 final progression-free survival analysis. Adv Ther. 2013; 30(10): 870884. PMid:24158787 http://dx.doi.org/10.1007/s12325-0 13-0060-1

[15] Anderson WF, Chatterjee N, Ershler WB, et al. Estrogen receptor breast cancer phenotypes in the Surveillance, Epidemiology, and End Results database. Breast Cancer Res Treat. 2002; 76(1): 27-36. http://dx.doi.org/10.1023/A : 1020299707510

[16] Setiawan VW, Monroe KR, Wilkens LR, et al. Breast cancer risk factors defined by estrogen and progesterone receptor status: the multiethnic cohort study. Am J Epidemiol. 2009; 169(10): 1251-1259. PMid:19318616 http://dx.doi.org/10.1093/aje/kwp036

[17] Johnston SRD. New strategies in estrogen receptor-positive breast cancer. Clin Cancer Res. 2010; 16(7): 1979-1987. PMid:20332324 http://dx.doi.org/10.1158/1078-0432.CCR-09-1823

[18] Chlebowski RT. Strategies to overcome endocrine therapy resistance in hormone receptor-positive advanced breast cancer. Clin Invest. 2014; 4(1): 19-33. http://dx.doi.org/10.4155/cli.13.123

[19] Hay N, Sonenberg N. Upstream and downstream of mTOR. Genes Dev. 2004; 18(16): 1926-1945. PMid:15314020 http://dx.doi.o $\mathrm{rg} / 10.1101 / \mathrm{gad} .1212704$

[20] Wullschleger S, Loewith R, Hall MN. TOR signaling in growth and metabolism. Cell. 2006; 124(3): 471-484. PMid:16469695 http://dx.doi.org/10.1016/j.cell.2006.01.016 
[21] Courtney KD, Corcoran RB, Engelman JA. The PI3K pathway as drug target in human cancer. J Clin Oncol. 2010; 28(6): 10751083. PMid:20085938 http://dx.doi.org/10.1200/JCD 200 9.25 .3641

[22] Cancer Genome Atlas Network. Comprehensive molecular portraits of human breast tumours. Nature. 2012; 490(7418): 61-70. PMid:23000897 http://dx.doi.org/10.1038/nature11412

[23] Castaneda CA, Cortes-Funes H, Gomez HL, et al. The phosphatidyl inositol 3-kinase/AKT signaling pathway in breast cancer. Cancer Metastasis Rev. 2010; 29(4): 751-759. PMid:20922461 http: //dx.doi.org/10.1007/s10555-010-9261-0

[24] Margariti N, Fox SB, Bottini A, et al. "Overcoming breast cancer drug resistance with mTOR inhibitors". Could it be a myth or a real possibility in the short-term future? Breast Cancer Res Treat. 2010; 128(3): 599-606. PMid:20945086 http://dx.doi.org/10.1007 /s10549-010-0986-9

[25] McAuliffe PF, Meric-Bernstam F, Mills GB, et al. Deciphering the role of $\mathrm{PI} 3 \mathrm{~K} / \mathrm{Akt} / \mathrm{mTOR}$ pathway in breast cancer biology and pathogenesis. Clin Breast Cancer. 2010; 10 Suppl 3: S59S65. PMid:21115423 http://dx.doi.org/10.3816/CBC. 2010. s.013

[26] Novartis Pharmaceuticals Corporation. Afinitor (everolimus) tablets for oral administration. Afinitor Disperz (everolimus tablets for oral suspension) [package insert]. East Hanover, NJ: Novartis Pharmaceuticals Corporation; 2015.

[27] Pfizer. Torisel Kit (temsirolimus) injection, for intravenous infusion only [package insert]. Philadelphia, PA: Pfizer; 2015.

[28] Ellard SL, Clemons M, Gelmon KA, et al. Randomized phase II study comparing two schedules of everolimus in patients with recurrent/metastatic breast cancer: NCIC Clinical Trials Group IND.163. J Clin Oncol. 2009; 27(27): 4536-4541. PMid:19687332 http://dx.doi.org/10.1200/JC0.2008.21.3033

[29] Bachelot T, Bourgier C, Cropet C, et al. Randomized phase II trial of everolimus in combination with tamoxifen in patients with hormone receptor-positive, human epidermal growth factor receptor 2-negative metastatic breast cancer with prior exposure to aromatase inhibitors: A GINECO study. J Clin Oncol. 2012; 30(22): 27182724. PMid:22565002 http://dx.doi.org/10.1200/JC0. 201 1.39.0708

[30] Baselga J, Semiglazov V, van Dam P, et al. Phase II randomized study of neoadjuvant everolimus plus letrozole compared with placebo plus letrozole in patients with estrogen receptor-positive breast cancer. J Clin Oncol. 2009; 27(16): 2630-2637. PMid:19380449 http://dx.doi.org/10.1200/JC0.2008.18.8391

[31] Andre F, Campone M, O'Regan R, et al. Phase I study of everolimus plus weekly paclitaxel and trastuzumab in patients with metastatic breast cancer pretreated with trastuzumab. J Clin Oncol. 2010; 28(34): 5110-5115. PMid:20975068 http://dx.doi.org/10.1200/JCO .2009 .27 .8549

[32] Schwarzlose-Schwarck S, Scholz CW, Regierer AC, et al. The mTOR inhibitor everolimus in combination with carboplatin in metastatic breast cancer-a phase I trial. Anticancer Res. 2012; 32(8): 3435-3441. PMid:22843927

[33] Wolff AC, Lazar AA, Bondarenko I, et al. Randomized phase III placebo-controlled trial of letrozole plus oral temsirolimus as first- line endocrine therapy in postmenopausal women with locally advanced or metastatic breast cancer. J Clin Oncol. 2013; 31(2): 195202. PMid:23233719 http://dx.doi.org/10.1200/JC0. 2011. 38.3331

[34] Chia S, Gandhi S, Joy AA, et al. Novel agents and associated toxicities of inhibitors of the PI3K/Akt/mtor pathway for the treatment of breast cancer. Curr Oncol. 2015; 22(1): 33-48. PMid:25684987 http://dx.doi.org/10.3747/co.22.2393

[35] Creel PA. Management of mTOR inhibitor side effects. Clin J Oncol Nurs. 2009; 13 Suppl: 19-23. PMid:19948456 http://dx.doi.o $\mathrm{rg} / 10.1188 / 09$. CJON.S2.19-23

[36] Peterson ME. Management of adverse events in patients with hormone receptor-positive breast cancer treated with everolimus: observations from a phase III clinical trial. Support Care Cancer. 2013; 21(8): 2341-2349. PMid:23686401 http://dx.doi.org/10.10 07/s00520-013-1826-3

[37] Porta C, Ostanto S, Ravaud A, et al. Management of adverse events associated with the use of everolimus in patients with advanced renal cell carcinoma. Eur J Cancer. 2011; 47: 1287-1298. PMid:21481584 http://dx.doi.org/10.1016/j.ejca.2011.02.014

[38] Moldawer NP, Wood LS. Management of key adverse events associated with everolimus therapy. Kidney Cancer J. 2010; 8: 51-59.

[39] White DA, Camus P, Endo M, et al. Noninfectious pneumonitis after everolimus therapy for advanced renal cell carcinoma. Am J Respir Crit Care Med. 2010; 182(3): 396-403. PMid:20194812 http://dx.doi.org/10.1164/rccm.200911-17200C

[40] Dabydeen DA, Jagannathan JP, Ramaiya N, et al. Pneumonitis associated with mTOR inhibitors therapy in patients with metastatic renal cell carcinoma: incidence, radiographic findings and correlation with clinical outcome. Eur J Cancer. 2012; 48(10): 15191524. PMid:22483544 http://dx.doi.org/10.1016/j.ejca. 2012.03 .012

[41] Motzer RJ, Escudier B, Oudard S, et al. Phase 3 trial of everolimus for metastatic renal cell carcinoma: final results and analysis of prognostic factors. Cancer. 2010; 116(8): 4256-4265. PMid:20549832 http://dx.doi.org/10.1002/cncr. 25219

[42] Rugo HS, Pritchard KI, Gnant M, et al. Incidence and time course of everolimus-related adverse events in postmenopausal women with hormone receptor-positive advanced breast cancer: insights from BOLERO-2. Ann Oncol. 2014; 25(4): 808-815. PMid:24615500 http://dx.doi.org/10.1093/annonc/mdu009

[43] Jerusalem G, Rorive A, Collignon J. Use of mTOR inhibitors in the treatment of breast cancer: an evaluation of factors that influence patient outcomes. Breast Cancer (Dove Med Press). 2014; 6: 43-57. http://dx.doi.org/10.2147/bctt.s38679

[44] Albiges L, Chamming's F, Duclos B, et al. Incidence and management of mTOR inhibitor-associated pneumonitis in patients with metastatic renal cell carcinoma. Ann Oncol. 2012; 23(8): 19431953. PMid:22689175 http://dx.doi.org/10.1093/annonc/ mds 115

[45] US Department of Health and Human Services. Common Terminology Criteria for Adverse Events (CTCAE). Version 4.03. 2010. Available from: http://evs.nci.nih.gov/ftp1/CTCAE/CTCAE _4.03_2010-06-14_QuickReference_5x7.pdf 